\title{
The Model of Territory Unit Evaluation for Allocation of Resources on Flood Protection
}

\author{
Jana Soukopová ${ }^{1}$ Eduard Bakoš ${ }^{2}$, Jan Šelešovský ${ }^{1}$, and Lenka Furová ${ }^{1}$ \\ ${ }^{1}$ Masaryk University, Faculty of Economics and Administration, \\ Department of Public Economics, Brno, Czech Republic \\ \{soukopova, jansel\} @econ.muni.cz, lenka.furova@gmail.com \\ ${ }^{2}$ University of Defence, Faculty of Economics and Management, Civil Protection Department \\ eduard.bakos@unob.cz
}

\begin{abstract}
Within implementation of Directive of the European Parliament and of the Council 2007/06/ES of 23 October 2007 on the assessment and management of flood risks the classification was recommended to Czech Republic which sorties the areas affected by floods according to the degree of threat and economic potential of these areas. For this purpose was developed the model of territory unit evaluation. This model is formulated as a combination of two models including model of risk matrix and model of the area value expressed by available statistical data. These data reflect the different levels of areas development and their possible future development through weighted multi-criteria decision making. The aim of our paper is to present the model and its use in terms of increasing the efficiency of spending resources in area in relation to flood protection. The model may serve as an inspiration in terms of use for such a large territorial units in European countries applying the Directive.
\end{abstract}

Keywords: Flood protection, territory unit, economic potential, damage.

\section{Introduction}

In economic sciences different categories which represent economic level, economic power, economic dimension, economic performance and economic potential of the territory unit are used. Usually are derived from the gross domestic product of the state, or from the gross domestic product per capita [5]. In a more sophisticated form are structured and decomposed into sub-indicators reflecting diversified sectorial and cross-cutting components. In a dynamic concept of the theory this indicators reflect performance factors, the country's competitiveness, development and growth potential based on multi-criteria basis. For example, categories of competitiveness of the national state have been in the U.S. in the eighties explicated not only theoretically, but also operationalized in government documents. However, it is debated to these days [4]. Similarly, the European Union puts the date in both the Lisbon strategy and the Europe 2020 strategy. In this context, as well as regular charts of the countries are compiled by some countries or international institutions. 
In a similar way, the economic power of territorial units within individual states [1] is defined. At the regional level are most commonly used categories of gross domestic product, but also other indicators describing the sub-segments of the economy of the monitored territory [3] can be used too. When determining the potential of regions is mostly based on the so-called "driving" factors, resulting in the identification of settlement patterns, economy and industry, demography and employment and social sphere [2] [6] [8 - 11]. Individual areas are associated with a set of relevant indicators. For multi-dimensional assessment of regional development could be used significance „trees“ of the factors, which is usually named „Ishikawa diagram“[7]. With this diagram can be described development potential of the area. Unlike this method there are other methods which could be used of assessment as is the method of paired comparisons, and other available methods. Partial indicators are then usually assigned appropriate weight and according to certain algorithms are aggregated.

Unlike the national view, where there is sufficient data base, for analysis, comparison and evaluation of lower level of territorial and administrative units are not always complex indicators and indicators. In the present paper, we offer one of the possible variants of creation the index of economic potential of the region, taking into account the available data base.

However, it is clear that in the regional domestic and foreign literature there are different approaches determining the economic potential of the region and are proposed different criteria and indicators for their synergistic expression. Compared to the macroeconomic level, there is much less consensus of experts.

The occurrences of many catastrophic floods in recent years led to significant increase interest of policies in improve flood protection. The main subject of discussion is the impact of measures to protect again negative effect of floods in individual regions and the influence of these measures on both economic growth and other economic fundamentals. This is directly connected with the problem of allocation of public spending in these areas.

The aim of our paper is to present the model of territory unit evaluation (hereinafter referred to as "the MTUE") and its use in terms of increasing the efficiency of spending resources in area in relation to flood protection. This model is formulated as a combination of two models including model of risk matrix and model of the area value. In developing Model of the Czech Republic, we came out the models available in literature.

\section{The Model of Territory Unit Evaluation}

The basic concept of the model is the assumption of its application for comparison of individual territorial units and for evaluation of efficiency of spending resources in area in relation to flood protection. The total amount of aid should be based on character of the affected area and risk of threats. The MTUE is developed for the evaluation territory unit. In the MTUE we have used the concept of risk matrix and the concept of economic potential of the area. 
The MTUE consist of the combination of two sub-models: the risk matrix model and the territory unit model.

\subsection{Risk Matrix Model}

The risk matrix model takes into account the risk of property loss and risk of human life loss in the territory unit.

The Property Loss. The coefficient of the property loss is based on potential loss of property during the floods. It is determined as follows:

$$
E m=w_{1} E m_{1}+w_{2} E m_{2}
$$

where $E m_{1}$ is the property loss,

$E m_{2}$ is the property loss in area with the property,

$w_{1,2}$ is the value for the coefficient.

The values were set 0.5 for both coefficient based on an expert assessment.

Risk of Human Life Loss. The coefficient of risk of human life loss is designed as weighted sum, see the following formula:

$$
E o=w_{1} E o_{1}+w_{2} E o_{2}
$$

where $E o_{1}$ is the coefficient of human life loss,

$E \mathrm{O}_{2}$ is the coefficient of human life loss per population of the territory (district),

$w_{1,2} \quad$ is the value for the coefficient.

The values were set 0.5 for both coefficient based on an expert assessment.

\subsection{Territory Unit Model}

Territory unit model comprises:

- basic indicators defining the territory (number of inhabitants and area, number inhabitants per ha);

- economic indicators considering the riches of the region from the perspective of tangible assets (property values and structures), investment and business (Foreign Direct Investment and number of business entities);

- income indicators (tax revenue per capita, average wage and employment).

The economic potential is then a function of the above variables:

$$
E p_{j}=f\left(x_{1}, \ldots, x_{n}\right)
$$

where $x_{i} \quad$ are variables affecting the value of the economic potential 
For the construction of the economic potential we used concept multi-criteria evaluation and weight point method. Thus

$$
E p_{j}=\sum_{i=1}^{7} e p_{i j} w_{i}
$$

where $E p_{j} \quad$ is the value of economic potential of $j$-territory unit, $j=1, \ldots, n$,

$e p_{1 j} \quad$ is the coefficient of population per hectare of the territory unit (TU),

$e p_{2 j} \quad$ is the coefficient values and structures of the property of the TU

$e p_{3 j} \quad$ is the coefficient of the tax revenue of the TU,

$e p_{4 j} \quad$ is a coefficient of the average salary of a TU,

$e p_{5 j} \quad$ is the coefficient of the employment of the TU,

$e p_{6 j} \quad$ is the coefficient representing the amount of foreign direct investment per capita of the TU,

$e p_{7 j} \quad$ is a coefficient representing the number of enterprises per inhabitant of the TU and $e p_{j} \in[0,1]$.

Subsequently, the expert review determined weights for individual coefficients, where:

$$
w_{1}=0.05, w_{2}=0.05, w_{3}=0.4, w_{4}=0.2, w_{5}=0.05, w_{6}=0.15, w_{7}=0.1 .
$$

Resulting evaluation of territory unit is then weighted coefficient of the above three coefficients:

$$
T U E_{j}=w_{1} E m_{j}+w_{2} E o_{j}+w_{3} E p_{j} \in\langle 0,1\rangle
$$

where $T U E_{j} \quad$ is $j$-TU evaluation, $j=1, \ldots, n$,

$E m_{j} \quad$ is the coefficient of risk of property loss of $j$-TU, $j=1, \ldots, n$,

$E o_{j} \quad$ is the coefficient of risk of human life loss of $j$-TU, $j=1, \ldots, n$,

$E p_{j} \quad$ is economic potential of $j$-TU, $j=1, \ldots, n$,

$w_{\mathrm{i}} \quad$ is standardise value for the coefficient.

The expert review determined weights for individual coefficients, where:

$$
w_{1}=0.3, w_{2}=0.3, w_{3}=0.4 \text {. }
$$

\section{Case Study in the Czech Republic}

The developed Model is constructed on the basis of available data in the Czech Republic. As the basic territory unit we choose district.

All coefficients used in Model are tracked and available and were determined on the basis of an expert assessment and the possibility of freely available data based on a database of the Czech Statistical Office and is available on www.czso.cz. The average wage is also based on company data, and server Profesia City for business operating on site http://www.mestoprobyznys.cz. Only in the case of tax revenues per 
capita, we use data from the Ministry of Finance. For the case study we choose the year 2010 with the exception of data which we obtained from the Ministry of Finance.

\subsection{The Property Loss of District}

Coefficient $E m_{1}$ was calculated according to loss of fixed assets of districts. Based on the distribution of the data the reference value of 3 billion CZK per year was determined by expert way. The districts that exceeded the reference values have been assigned a value of 1 . Data of other districts were recalculated as a proportion of potentially affected assets by flood in million CZK per year and the reference value.

Coefficient $\mathrm{Em}_{2}$ was calculated as the proportion of potentially affected property by floods in urban area of the region (district). Based on the distribution of the data the reference value for the calculation of coefficient was set out 1.5 million CZK. The districts that exceeded the reference value have been assigned a value of 1. Data of other district were recalculated according to the following formula:

$$
E m_{2 j}=\frac{M_{j}}{Z U_{j}}
$$

where $\quad M_{j} \quad$ is value of potentially affected property by floods in million CZK per year,

$Z U_{j} \quad$ is the urban area of district $j$ in ha, where $j=1, \ldots, n(n=76)$.

\subsection{Human Life Loss of District}

Coefficient $E o_{1}$ was calculated according human life loss of district. Based on the distribution of the data the reference value of 1000 inhabitants per year was determined by expert way. The districts that exceeded the reference value have been assigned a value of 1 . Data of other district were recalculated as a proportion of human life loss of the district per year and reference value.

Coefficient $\mathrm{EO}_{2}$ was calculated as a proportion of human life loss per population of territory (district). When calculating the risk of human life loss we have used data on the number of inhabitants of the territory in 2010. Based on the distribution of data the reference value for the calculation of the coefficient was set out 0.01. Data of other districts was recalculated as the proportion of the human life loss per population of territory in year and reference value.

\subsection{The Economic Potential of the District}

Coefficient of population per hectare. For the purpose of the creation this coefficient was used indicator on the total area of the region (district). As a reference value was determined by expert assessment value of 10 inhabitants per hectare. This value is 
based on the distribution of the data. While districts that exceed this value were assigned a value of 1 and other districts of the coefficient of population per hectare of the district recalculated using the following formula:

$$
e p_{1 j}=\frac{P o_{j}}{10}
$$

where $P o_{j} \quad$ is the number of inhabitants per hectare.

Coefficient values and structures of the property. The value and structure of assets is based on the conversion of built up area to the total area of the region. For this indicator was using the expert assessment of the minimum reference value of $10 \%$. This is based on data distribution. Districts with the reference value higher $10 \%$ assigned value 1.In other districts the coefficient values and structures of assets is calculated using the following formula:

$$
e p_{2 j}=\frac{S M_{j}}{0,1}
$$

where $S M_{j} \quad$ is the proportion of built-up areas and courtyards in the total area.

Coefficient of the tax revenue. In the case of tax revenues per capita, we use data from the Ministry of Finance. The reference value was determined according to the distribution function of 50 thousand CZK. This is based on data distribution. Districts with tax revenues per capita higher than reference value assigned value 1 . Other values were recalculated using the following formula:

$$
e p_{3 j}=\frac{D}{50,000}
$$

where $\quad D_{j} \quad$ is $j$-district tax revenue per capita.

Coefficient of the average salary. For the conversion coefficient of the average wage was, according to the distribution of the dataset reference minimum average wage of 26 thousand CZK. This value exceeds only districts: Prague, Mladá Boleslav, Brno city and Pilsen-city. Average wages were recalculated using reference value. When districts exceeded this value they were assigned a value of 1 . In other districts the coefficient values and structures of assets is calculated using the following formula:

$$
e p_{4 j}=\frac{m_{j}}{26,000}
$$

where $\quad m_{j} \quad$ is the average wage in $j$-district.

Coefficient of employment based on the unemployment rate in the districts. The reference value was determined natural rate of unemployment at $4 \%$. Taking districts, who had lower unemployment than $4 \%$, has been assigned a value of 1 . Other districts were assigned a value according to the following formula:

$$
e p_{5 j}=\frac{0,04}{u_{j}}
$$

where $u_{j}$ is the unemployment rate of the district 
Coefficient of foreign direct investment was based on the foreign direct investment. For this indicator was using the expert assessment of the minimum reference value 400 thousand CZK per capita. This is based on data distribution. Districts that the reference value exceeded 400 thousand CZK per capita has been assigned the value of 1. In other districts the average coefficient of FDI is calculated according to following formula:

$$
e p_{6 j}=\frac{P Z I_{j}}{400,000}
$$

where $P Z I_{j}$ is the average foreign direct investment flowing into the $j$-district.

Coefficient of enterprises. Coefficient of enterprises is constructed by dividing the number of business entities in the population. For the construction was used data from year 2010. As reference value was used 0.32. This is based on data distribution. Counties that exceeded the reference value (only districts Prague and Brno-city) was assigned a value of 1 . In other districts the coefficient values and structures of assets is calculated using the following formula:

$$
e p_{7 j}=\frac{E S_{j}}{0.32}
$$

Subsequently, it was determined coefficient of the economic potential of the district according to the formula (4). A coefficient of the economic potential is shown in next figure.

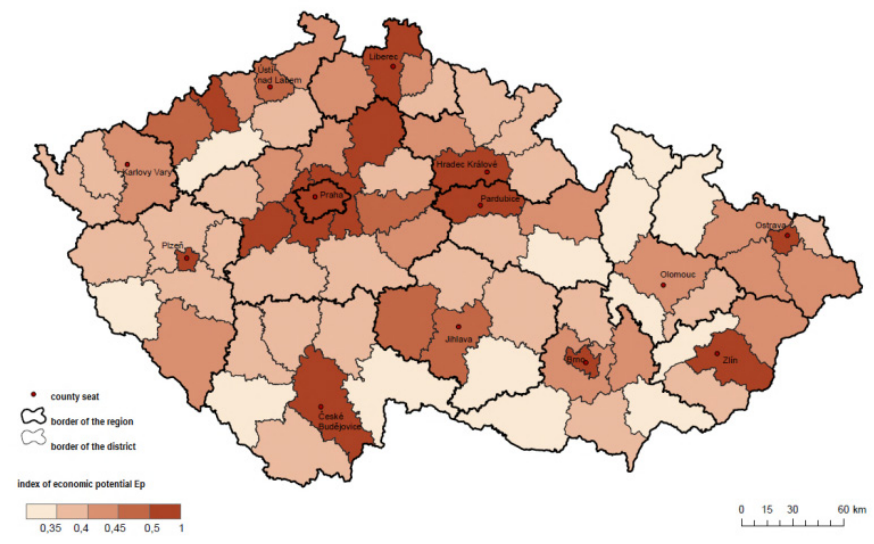

Fig. 1. Map of economic potential for the districts of the Czech Republic in 2010 (Source: Authors)

\section{$4 \quad$ Results and Discussion}

The coefficient of the territory value evaluation of the district according to the formula (5) is shown in next table. 
Table 1. Coefficient of the district value in the Czech Republic in 2010 (Source: Authors)

\begin{tabular}{|c|c|c|c|c|c|c|c|c|c|}
\hline District & Em & Eo & Ep & TUE & District & Em & Eo & $E p$ & TUE \\
\hline Praha & 1,00 & 0,41 & 1,00 & 0,82 & Liberec & 0,71 & 0,73 & 0,93 & 0,81 \\
\hline Benešov & 0,13 & 0,06 & 0,40 & 0,22 & Semily & 0,41 & 0,41 & 0,80 & 0,56 \\
\hline Beroun & 0,24 & 0,17 & 0,63 & 0,38 & Hradec Králové & 0,40 & 0,26 & 0,80 & 0,52 \\
\hline Kladno & 0,22 & 0,08 & 0,46 & 0,27 & Jičín & 0,14 & 0,25 & 0,74 & 0,41 \\
\hline Kolín & 0,25 & 0,23 & 0,49 & 0,34 & Náchod & 0,65 & 1,00 & 0,71 & 0,78 \\
\hline KutnáHora & 0,17 & 0,17 & 0,45 & 0,28 & RychnovnadKněžnou & 0,15 & 0,39 & 0,68 & 0,43 \\
\hline Mělník & 0,92 & 0,49 & 0,47 & 0,61 & Trutnov & 0,45 & 0,94 & 0,76 & 0,72 \\
\hline MladáBoleslav & 1,00 & 0,50 & 0,88 & 0,80 & Chrudim & 0,13 & 0,25 & 0,38 & 0,27 \\
\hline Nymburk & 0,30 & 0,28 & 0,38 & 0,33 & Pardubice & 0,20 & 0,08 & 0,66 & 0,35 \\
\hline Praha-východ & 0,22 & 0,08 & 0,72 & 0,38 & Svitavy & 0,17 & 0,72 & 0,76 & 0,57 \\
\hline Praha-západ & 0,28 & 0,10 & 0,61 & 0,36 & Ústí nad Orlicí & 0,53 & 1,00 & 0,59 & 0,70 \\
\hline Příbram & 0,10 & 0,07 & 0,39 & 0,21 & Havlíčkův Brod & 0,09 & 0,04 & 0,38 & 0,19 \\
\hline Rakovník & 0,17 & 0,04 & 0,42 & 0,23 & Jihlava & 0,29 & 0,12 & 0,52 & 0,33 \\
\hline České Budějovice & 0,66 & 0,33 & 0,69 & 0,57 & Pelhřimov & 0,06 & 0,06 & 0,50 & 0,24 \\
\hline Český Krumlov & 0,20 & 0,13 & 0,39 & 0,26 & Třebíč & 0,15 & 0,12 & 0,34 & 0,21 \\
\hline Jindřichův Hradec & 0,14 & 0,14 & 0,35 & 0,22 & Žd'árnadSázavou & 0,10 & 0,08 & 0,38 & 0,20 \\
\hline Písek & 0,10 & 0,25 & 0,41 & 0,27 & Blansko & 0,20 & 0,11 & 0,37 & 0,24 \\
\hline Prachatice & 0,18 & 0,18 & 0,33 & 0,24 & Brno-město & 0,62 & 0,23 & 0,86 & 0,60 \\
\hline Strakonice & 0,19 & 0,24 & 0,37 & 0,28 & Brno-venkov & 0,30 & 0,29 & 0,45 & 0,36 \\
\hline Tábor & 0,31 & 0,19 & 0,41 & 0,32 & Břeclav & 0,16 & 0,11 & 0,40 & 0,24 \\
\hline Domažlice & 0,05 & 0,17 & 0,36 & 0,21 & Hodonín & 0,05 & 0,03 & 0,36 & 0,17 \\
\hline Klatovy & 0,29 & 0,43 & 0,44 & 0,39 & Vyškov & 0,10 & 0,31 & 0,43 & 0,29 \\
\hline Plzeň-město & 0,71 & 0,05 & 0,86 & 0,57 & Znojmo & 0,02 & 0,01 & 0,36 & 0,15 \\
\hline Plzeň-jih & 0,06 & 0,07 & 0,39 & 0,19 & Jeseník & 0,08 & 0,14 & 0,33 & 0,20 \\
\hline Plzeň-sever & 0,13 & 0,21 & 0,39 & 0,26 & Olomouc & 0,79 & $\mathbf{1 , 0 0}$ & 0,45 & 0,72 \\
\hline Rokycany & 0,11 & 0,29 & 0,42 & 0,29 & Prostějov & 0,03 & 0,01 & 0,37 & 0,16 \\
\hline Tachov & 0,22 & 0,10 & 0,40 & 0,25 & Přerov & 0,74 & 0,98 & 0,39 & 0,67 \\
\hline Cheb & 0,14 & 0,08 & 0,39 & 0,22 & Šumperk & 0,54 & 1,00 & 0,36 & 0,61 \\
\hline Karlovy Vary & 0,45 & 0,07 & 0,43 & 0,33 & Kroměříž & 0,31 & 0,73 & 0,34 & 0,45 \\
\hline Sokolov & 0,41 & 0,59 & 0,38 & 0,45 & Uherské Hradiště & 0,23 & 0,46 & 0,38 & 0,36 \\
\hline Děčín & 0,51 & 0,31 & 0,46 & 0,43 & Vsetín & 0,43 & 0,66 & 0,42 & 0,50 \\
\hline Chomutov & 0,27 & 0,11 & 0,49 & 0,31 & Zlín & 0,70 & 0,83 & 0,59 & 0,70 \\
\hline Litoměřice & 0,99 & 0,44 & 0,41 & 0,59 & Bruntál & 0,21 & 0,40 & 0,32 & 0,31 \\
\hline Louny & 0,35 & 0,19 & 0,35 & 0,30 & Frýdek-Místek & 0,14 & 0,34 & 0,46 & 0,33 \\
\hline Most & 0,13 & 0,02 & 0,56 & 0,27 & Karviná & 0,22 & 0,21 & 0,37 & 0,28 \\
\hline Teplice & 0,09 & 0,06 & 0,46 & 0,23 & NovýJičín & 0,11 & 0,17 & 0,42 & 0,25 \\
\hline Ústí nad Labem & 0,64 & 0,21 & 0,51 & 0,46 & Opava & 0,13 & 0,15 & 0,41 & 0,25 \\
\hline Česká Lípa & 0,15 & 0,27 & 0,46 & 0,31 & Ostrava-město & 0,22 & 0,05 & 0,92 & 0,45 \\
\hline Jablonec nad Nisou & 0,33 & 0,37 & 0,45 & 0,39 & & & & & \\
\hline
\end{tabular}


For the expression of economic potential of the region there are not always sufficient sources of data. This is probably one of the reasons why experts in this research area design different patterns and indicators which are usually based on the available information. Diversification in view of economic (social-economic) aspects of the described area is also conditioned their professional orientation (e.g. regionalists, economists, experts in labour market and social policy, etc.). In this sense, there is no uniform methodology for the evaluation of territorial or administrative units of state, or this approach has own purposeful nature (e.g. comparison of cohesion regions NUTS 2 within regional policy of EU). If the data exist (e.g. gross domestic product), then could be this data apply generally to the middle level of territorial units or public administration of the country. For lower levels the synthetic economic characteristics are not usually stated and are published only partial indicators such as population, unemployment, etc.

Therefore, we recommended using for assessment of regional development for named lower level of territorial units (on the example of district in the Czech Republic) the appropriate indicators and their immanent coefficients (population per hectare of the district, the value and structure of the property in district, the tax revenue of the district, the average wage of the district, employment the district, the amount of foreign direct investment per capita in district and the number of enterprises of the district).

Number of indicators is not random. It is not only based on their traceability but also from expert panel. Using only one or two indicators could possibly lead to distortion in description of real economic power of examined territorial units. Distortion is to a certain extent reduced by using multi-criteria evaluation. It is obvious that into account could be taken other indicators (e.g. purchasing power of population). However, on the one hand with the rise in number of indicators the complexity of the calculation is increased, on the other hand their marginal value added decreases, as many indicators correlate or have some substitutes. For example, the purchasing power of the population is usually conditioned the average wage of reporting district, that is not a border tourist destination. It is therefore a selection of indicators that are available, complementary and balance, and while providing relatively easy operationalize.

\section{Conclusion}

The proposed structure of economic potential of region may have a wide application, e.g. in developing strategic, conceptual and program documents of public administration on the state or regional level, especially in regional politics, when deciding how to allocate resources in the area and establish the priorities for disparately regions. In our case this procedure, calculation respectively, has been use in the context of the project which examined the flood risk in flood affected districts in the Czech Republic in terms of flood protection. In addition to the categorization of floodplains according to frequency of recurring floods and flood of threat (Q20, Q50, Q100, etc.), the classification of districts according to their economic potential was performed. Based on their interaction there was recommended model for determination of order for invest- 
ment in flood protection. This case study shows practical applicability of assessment of regional development within the investment in the region. Much more could be done to improve this model. That could be subject of further research.

Acknowledgements. This article has been elaborated as one of the findings of specific research project MUNI/A/0786/2012 "Quality evaluation of public policies in the context of restrictive constraints of public finances".

\section{References}

1. Armstrong, M., De Kervenoael, R.J., Li, X., Read, R.: A comparison of the economic performance of different micro-states, and between micro-states and larger countries. World Dev. 26, 639-656 (1998)

2. Agarwal, S., Rahman, S., Errington, A.: Measuring the determinants of relative economic performance of rural areas. J. Rural Stud. 25, 309-321 (2009)

3. Bai, C., Ma, H., Pan, W.: Spatial spillover and regional economic growth in China. China Econ. Rev. 23, 982-990 (2012)

4. Delgado, M., Ketels, C., Porter, M.E., Stern, S.: The Determinants of National Competitiveness, NBER Working Paper No. 18249 (2012)

5. Chlad, M.: Diferencovaný ekonomický rozvoj v regionech ČR - potřeba makroekonomických indikátorů pro řízení v regionech. Urbanismus a územní rozvoj 5, 40-43 (2010)

6. Llner, M., Kostelecký, T., Patočková, V.: Jak fungují kraje - příspěvek k hodnocení výkonu krajských vlád. Sociol cas. 43, 967-992 (2007)

7. Ishikawa, K.: Guide to Quality Control. JUSE, Tokyo (1968)

8. Kostelecký, T., Patočková, V., Vobecká, J.: Kraje v České republice - existujísouvislosti mezi ekonomickým rozvojem, sociálním kapitálem a výkonem krajských vlád? Sociol Cas. 43, 911-944 (2007)

9. Malý, I.: Veřejné statky a veřejně poskytované statky. Polit ekon 46, 861-868 (1998)

10. Porter, M.E.: The economic performance of regions. Reg. Stud. 37, 549-578 (2003)

11. Terluin, I.J.: Differences in economic development in rural regions of advanced countries an overview and critical analysis of theories. J. Rural Stud. 19, 327-344 (2009) 